\title{
Fourth Stage of Labor
}

National Cancer Institute

\section{Source}

National Cancer Institute. Fourth Stage of Labor. NCI Thesaurus. Code C92802.

A stage during labor and childbirth that starts with the delivery of the placenta and lasts about two hours after delivering the baby. 